\title{
Kasvun ja vanhenemisen tutkijat ry
}

Kasvua ja vanhenemista käsittelevälle tutkimukselle on ollut tyypillistä, että elämänkaaren vaiheita on tarkasteltu erillisinä. Lapsuus ja nuoruus ovat muodostaneet yhden kokonaisuuden, joka on ollut erityisesti kehityspsykologien tutkimuskohteena. Gerontologit eli vanhenemisen tutkijat ovat puolestaan keskittyneet elämänkaaren loppupäähän ja pyrkineet selvittämään nimenomaan vanhenemiseen liittyvää problematiikkaa. Elämänkaaren vaiheista aikuis- ja keski-ikä ovat jääneet tutkimustoiminnassa selvästi vähäisimmälle huomiolle. Elämänkaaren keskiosa ei ole näyttänyt kiinnostavan tutkijoita läheskään samassa määrin kuin ääripäät. Vaikka tutkimuskohde elämänkaaritutkimuksessa eri tieteenaloilla on tavallaan sama, tieteiden välinen yhteistyö on näihin päiviin asti ollut varsin vähäistä.

Viime vuosina on kuitenkin tieteiden välinen yhteistyö kasvun ja vanhenemisen tutkimuksessa lisääntynyt. Toisaalta on alettu tehdä yhä enemmän pitkittäistutkimuksia aikaisempien poikkileikkaustutkimusten asemesta. Toisin sanoen elämänkaarta on ryhdytty tarkastelemaan sen pitkittäissuunnassa.

Yhtenä osoituksena tällä tutkimusalueella tapahtunees- ta kiinnostuksen lisääntymisestä on uuden tieteellisen yhdistyksen syntyminen. Vuoden 1980 lopussa perustettiin tieteellinen yhdistys, Kasvun ja vanhenemisen tutkijat ry., jonka ensisijaisena tarkoituksena on koota yhteen kasvun ja vanhenemisen tutkimuksesta kiinnostuneita tutkijoita eri tieteenaloilta ja edistää tieteiden välistä yhteistyötä. Käytännössä tämä tapahtuu mm. konferensseja, seminaareja ja kokouksia järjestämällä sekä harjoittamalla ja tukemalla alan julkaisutoimintaa. Muita keskeisiä alueita yhdistyksen toiminnassa ovat: osallistuminen alan kansainväliseen yhteistoimintaan, tieteellisen jatko- ja täydennyskoulutuksen kehittäminen sekä yleensä yhteydenpito eri puolilla maata ja eri tieteenaloilla työskentelevien kasvun ja vanhenemisen tutkijoiden välillä.

Yhdistyksen puheenjohtajana on professori Eino Heikkinen (terveystieteen laitos, Jyväskylän yliopisto) ja varapuheenjohtajana professori Isto Ruoppila (psykologian laitos, Jyväskylän yliopisto). Hallituksen muut jäsenet ovat Antti Hervonen (Tampereen yliopisto), Yrjö-Paavo Häyrynen (Joensuun korkeakoulu), Pertti Pohjolainen (Tampereen yliopisto), Jan-Erik Ruth (Kuntokallio-opisto), Tapani Sihvola (Kuntokallio- opisto) sekä varajäseninä Marja Jylhä (Tampereen yliopisto) ja Simo Koskinen (Tampereen yliopisto). Yhdistyksen sihteerinä toimii Harri Suominen (terveystieteen laitos, Jyväskylän yliopisto, 40100 Jyväskylä 10). Yhdistyksen toiminnasta kiinnostuneet voivat ottaa yhteyttä joko sihteeriin tai johonkin hallituksen jäseneen.

Vuoden 1981 marraskuussa Kasvun ja vanhenemisen tutkijat ry. järjesti Suomen Akatemian tuella Laukaassa seminaarin "Kasvun ja vanhenemisen tutkimusseminaari", johon osallistui noin 80 tutkijaa eri puolilta maata. Seminaarista on ilmestynyt seminaariraportti, jossa pääesitelmät on julkaistu. Vuonna 1982 yhdistys järjesti kaksi pienimuotoisempaa symposiumia toisen toukokuussa Tampereella ja toisen marraskuussa Jyväskylässä. Seuraava tällainen symposiumi järjestetään Turussa maaliskuussa 1983. Kansainvälisestä toiminnasta mainittakoon, että yhdistys oli järjestämässä $\mathrm{mm}$. Pohjoismaisiin tutkijakursseihin kuuluvaa seminaaria "Teoretiska och metodologiska frågor i den gerontologiska forskningen", joka pidettiin syyskuussa 1981 .

Pertti Pohjolainen 